\title{
HUBUNGAN PENGETAHUAN DAN SIKAP PASIEN HIPERTENSI TERHADAP KEPATUHAN PENGGUNAAN OBAT AMLODIPIN DI PUSKESMAS ARJUNO KOTA MALANG
}

\author{
Taufik Haldi ${ }^{1}{ }^{*}$, Liza Pristianty ${ }^{2}$, Ika Ratna Hidayati $^{1}$ \\ ${ }^{1}$ Prodi Farmasi, Fakultas Ilmu Kesehatan, Universitas Muhammadiyah Malang \\ Jl. Bendungan Sutami No.188, Malang 65145, Indonesia \\ ${ }^{2}$ Fakultas Farmasi, Universitas Airlangga \\ Gedung Nanizar Zaman Joenoes Kampus C, Jl. Ir. Soekarno, Surabaya 60115, Indonesia \\ Email: taufikhaldi418@gmail.com
}

\begin{abstract}
ABSTRAK
Hipertensi merupakan penyakit yang memiliki angka prevalensi yang tinggi. Hipertensi dapat distabilkan dengan melakukan pola hidup yang sehat dan menggunakan obat antihipertensi, salah satunya amlodipin. Penggunaan obat amlodipin diperlukan kepatuhan agar hipertensi dapat terkontrol. Kepatuhan pasien dalam melaksanakan pengobatan harus dipertahankan dalam jangka waktu yang lama, oleh sebab itu pasien harus memiliki pengetahuan yang baik dan sikap yang positif terhadap hipertensi. Tujuan penelitian ini adalah untuk mengetahui hubungan pengetahuan dan sikap pasien hipertensi terhadap kepatuhan penggunaan obat amlodipin di Puskesmas Arjuno Kota Malang. Desain penelitian yang digunakan adalah metode observasional analitik dengan pendekatan cross-sectional. Data dikumpulkan dengan memberikan kuesioner kepada 76 responden yang memenuhi kriteria inklusi pada bulan AgustusSeptember 2019 di Puskesmas Arjuno Kota Malang. Hasil dari penelitian ini menunjukkan bahwa 59\% pasien memiliki pengetahuan yang baik, $18 \%$ cukup baik, $12 \%$ kurang baik, dan $11 \%$ tidak baik. Pasien yang memiliki sikap positif sebanyak $59 \%$ dan bersikap negatif sebanyak $41 \%$. Pasien yang patuh berjumlah $74 \%$ dan tidak patuh sebanyak $26 \%$. Hasil uji chi square antara pengetahuan terhadap kepatuhan menunjukkan adanya perbedaan bermakna pada kelompok pengetahuan terhadap kepatuhan minum obat $(\mathrm{p}$-value $=0,031)$. Begitu pula dengan kelompok pada Sikap terhadap kepatuhan, memberikan hasil berbeda bermakna ( $\mathrm{p}$-value $=0,002)$. Uji regresi logistik pada pengetahuan dan sikap diuji secara bersamaan terhadap kepatuhan dan didapatkan masing-masing nilai p-value 0,026 $(\mathrm{OR}=$ 1,794) dan 0,005 (OR = 5,208). Pengetahuan dan sikap pasien hipertensi harus terus ditingkatkan sehingga perilaku patuh minum obat dapat meningkat.
\end{abstract}

Kata kunci: pengetahuan, sikap, kepatuhan, amlodipine, hipertensi

\begin{abstract}
Hypertension is a disease that has a high prevalence rate. Hypertension can be stabilized by implementing healthy life pattern and by using hypertension drugs, one of them is amlodipine. The use of amlodipine needs adherence in order that the hypertension can be controlled. The patients' adherence in getting treatment must be maintained in long period of time. Therefore, the patients should have good knowledge and positive attitude with hypertension. Objective of this research was to determine the difference between knowledge categories and attitude categories of hypertension patients toward medication adherence with the use of amlodipine at Public Health Arjuno Malang. The research design used was analytical-observational method with cross-sectional approach. The data was collected by distributing questionnaire consisting of 76 respondents who meet the inclusion criteria in August-September 2019 at Community Healthcare Service Arjuno Malang. The result of this research showed that the 59\% respondents had good knowledge, $18 \%$ had quite good knowledge, $12 \%$ had less good knowledge, and $11 \%$ had not good knowledge. There were 59\% respondents who had positive attitude and $41 \%$ had negative attitude towards adhere to amlodipine treatment. There were $74 \%$ respondents who were adhere and $26 \%$ who were not adhere to the amlodipine regimen. The result of chi square test showed significant difference between knowledge and adherence $(p$-value $=0.031)$ and attitude toward adherence $(p$-value $=$ 0.002). In logistic regression test, knowledge and attitude were tested simultaneously and the p-value
\end{abstract}


respectively were $0.026(\mathrm{OR}=1.794)$ and $0.005(\mathrm{OR}=5.208)$. Pharmacist effort to increase knowledge and attitude should be maintain so the medication adherence will be increased as well.

Keywords: knowledge, attitude, adherence, amlodipine, hypertension

\section{PENDAHULUAN}

Hipertensi adalah gangguan vaskular yang ditandai dengan tekanan darah sistolik sama dengan atau diatas $140 \mathrm{mmHg}$ dan/atau tekanan darah diastolik sama dengan atau diatas 90 mmHg. Hipertensi sering tidak menimbulkan gejala sehingga juga di sebut sillent killer. Hipertensi tidak memberikan gejala kepada penderita, namun bukan berarti tidak berbahaya, dalam jangka waktu yang lama dapat menimbulkan komplikasi. Oleh karena itu, hipertensi dideteksi dini dengan pemeriksaan tekanan darah secara berkala (Depkes RI, 2012).

Hipertensi merupakan suatu penyakit dengan angka mortalitas dan morbiditas yang sangat tinggi di dunia. Penyakit hipertensi telah menjadi masalah utama dalam kesehatan masyarakat yang ada di Indonesia maupun di beberapa negara yang ada di dunia. Diperkirakan sekitar 80\% kenaikan kasus hipertensi terutama di negara berkembang tahun 2025 dari sejumlah 639 juta kasus di tahun 2000, diperkirakan menjadi 1,15 milyar kasus di tahun 2025 (Sinuraya et al, 2018).

Ada dua terapi yang dilakukan untuk mengobati hipertensi yaitu terapi non farmakologis dan terapi farmakologis. Terapi non farmakologis dapat dilakukan dengan modifikasi gaya hidup yang meliputi berhenti merokok, melakuan diet berat badan, menghindari alkohol, serta yang mencakup psikis antara lain menghindari stres, melakukan olahraga, dan istirahat yang cukup. Sedangkan terapi farmakologis menggunakan obat-obatan antihipertensi yang dapat menurunkan tekanan darah. Golongan obat antihipertensi antara lain beta blocker, angiotensin II receptor blocker (ARB), angiostensin converting enzym inhibitor (ACEI), diuretic, dan calcium channel blocker dianggap sebagai obat antihipertensi utama dan salah satunya obat amlodipin untuk pengendalian tekanan darah tinggi. Amlodipin merupakan obat antihipertensi yang sering digunakan untuk terapi hipertensi. Amlodipin tergolong dalam obat antagonis kalsium golongan dihidropiridin (antagonis ion kalsium). Amlodipin obat yang dikonsumsi dalam jangka panjang, maka diperlukan kepatuhan pasien dalam menggunakan obat ini (Soenarto et al, 2015).
Kepatuhan minum obat amlodipin sangat penting karena dengan minum obat antihipertensi secara teratur dapat mengontrol tekanan darah penderita hipertensi. Sehingga dalam jangka panjang risiko kerusakan organorgan penting tubuh seperti jantung, ginjal, dan otak dapat dikurangi. Oleh karena itu, diperlukan pemilihan obat yang tepat agar dapat meningkatkan kepatuhan dan mengurangi risiko kematian (Gama et al, 2014). Kepatuhan merupakan perilaku kesehatan.

Menurut Lawrance Green perilaku kesehatan di pengaruhi oleh 3 faktor utama yaitu faktor predisposisi, faktor pendukung, dan faktor pendorong. Faktor predisposisi terdiri dari pengetahuan dan sikap. Pengetahuan merupakan pengindraan melalui panca indra manusia, yakni indra penglihatan, pendengaran, penciuman, rasa, dan raba. Sedangkan merupakan reaksi atau respons yang masih tertutup dari seseorang terhadap suatu stimulus atau objek. Perilaku yang didasari oleh pengetahuan yang baik dan sikap yang positif akan menghasilkan perilaku yang berlangsung lama (Notoadmodjo, 2012). Tujuan penelitian ini adalah untuk mengetahui hubungan antara pengetahuan dan sikap pasien hipertensi terhadap kepatuhan penggunaan obat amlodipin di Puskesmas Arjuno Kota Malang.

\section{METODE PENELITIAN}

Penelitian ini dilakukan pada bulan AgustusSeptember 2019 di Puskesmas Arjuno Kota Malang. Metode Penelitian yang digunakan yaitu observasional analitik dengan pendekatan cross sectional. Instrumen digunakan berupa kuesioner yang diberikan pada masing-masing responden yang menjadi sampel. Pengambilan sampel penelitian ini dilakukan dengan metode purposive sampling dengan cara memilih sampel berdasarkan kriteria inklusi yang sudah ditentukan.

Penentuan ukuran sampel menggunakan rumus Slovin didapatkan hasil sebanyak 76 pasien untuk menjadi sampel pada penelitian ini.

\section{HASIL DAN PEMBAHASAN}

Dari survei penelitian yang dilakukan pada bulan Agustus-September 2019 di Puskesmas 
Arjuno Kota Malang diperoleh 76 responden yang memenuhi kriteria inklusi. Dari hasil pengumpulan kuesioner didapatkan data demografi pasien meliputi usia, jenis kelamin, pendidikan, dan pekerjaan dapat dilihat pada Tabel 1.

Tabel 1. Demografi Pasien

\begin{tabular}{clcc}
\hline \hline Karakteristik Demografi & & Frekuensi (orang) & Persentase (\%) \\
\hline \multirow{5}{*}{ Usia (tahun) } & $>46$ & 5 & $7 \%$ \\
& $45-59$ & 27 & $36 \%$ \\
& $60-74$ & 36 & $47 \%$ \\
& $<74$ & 8 & $10 \%$ \\
\hline \multirow{2}{*}{ Jenis Kelamin } & Laki-laki & 28 & $37 \%$ \\
& Perempuan & 48 & $63 \%$ \\
\hline \multirow{5}{*}{ Pekerjaan } & PNS & 2 & $3 \%$ \\
& Karyawan & 9 & $12 \%$ \\
& Swasta & & \\
& Wiraswasta & 24 & $31 \%$ \\
& Ibu Rumah & 41 & $54 \%$ \\
& Tangga & & \\
\hline \multirow{5}{*}{ Pendidikan } & SD/sederajat & 31 & $41 \%$ \\
& SMP/sederajat & 17 & $22 \%$ \\
& SMA/sederajat & 19 & $25 \%$ \\
& Diploma/S1 & 9 & $12 \%$ \\
& SD/sederajat & 31 & $41 \%$ \\
\hline \hline
\end{tabular}

Berdasarkan Tabel 1 didapatkan hasil data demografi pasien paling banyak berjenis kelamin perempuan (63\%), berumur 60-74 tahun (47\%), dengan tingkat pendidikan paling banyak yaitu SD/sederajat $(41 \%)$ dan sebagai ibu rumah tangga (54\%).

Penilaian kuesioner pengetahuan dilakukan dengan membandingkan jumlah skor jawaban yang benar dengan jumlah pernyataan kemudian dikalikan $100 \%$ dan hasilnya berupa persentase pengetahuan. Dari hasil tersebut maka dapat dikategorikan pengetahuan responden. Hasil tersebut dapat dilihat pada Tabel 2 .

Tabel 2. Kategori Pengetahuan Pasien

\begin{tabular}{lll}
\hline \hline $\begin{array}{l}\text { Kategori } \\
\text { pengetahuan }\end{array}$ & $\begin{array}{l}\text { Frekuensi } \\
\text { (orang) }\end{array}$ & $\begin{array}{l}\text { Persentase } \\
(\%)\end{array}$ \\
\hline Baik & 45 & $59 \%$ \\
Cukup & 14 & $18 \%$ \\
Kurang baik & 9 & $12 \%$ \\
Tidak baik & 8 & $11 \%$ \\
\hline Total & 76 & $100 \%$ \\
\hline
\end{tabular}

Berdasarkan Tabel 2 didapatkan bahwa 59\% pasien yang memiliki pengetahuan yang baik, $18 \%$ cukup baik, $12 \%$ kurang baik

, 11\% tidak baik. Pengetahuan adalah hasil pengindraan manusia atau hasil tahu seseorang terhadap objek melalui indra yang dimilikinya (mata, hidung, telinga dan sebagainya). Pasien umumnya menerima informasi pada saat konseling dengan apoteker ketika pengambilan obat. Dengan demikian, perlu adanya peningkatan edukasi terkait penggunaan obat antihipertensi melalui promosi kesehatan.
Dibutuhkan peran tenaga kesehatan seperti apoteker dalam memberikan program promosi kesehatan termasuk edukasi kepada masyarakat terkait penggunaan obat antihipertensi yang benar. Pengetahuan tentang terapi hipertensi yang memadahi secara langsung akan berdampak pada kepatuhan penggunaan obat antihipertensi termasuk amlodipin (Sinuraya et al, 2017).

Pada Tabel 3 didapatkan data tentang sikap positif maupun sikap negatif pasien terhadap penggunaan obat amlodipin.

Tabel 3. Kategori Sikap Pasien

\begin{tabular}{lll}
\hline \hline Kategori sikap & $\begin{array}{l}\text { Frekuensi } \\
\text { (orang) }\end{array}$ & Persentase (\%) \\
\hline Positif & 45 & $59 \%$ \\
Negatif & 31 & $41 \%$ \\
\hline Total & 76 & $100 \%$ \\
\hline \hline
\end{tabular}

Berdasarkan Tabel 3 didapatkan data 59\% responden bersikap positif dan $41 \%$ bersikap negatif. Hasil tersebut menggambarkan bahwa pasien yang memiliki sikap positif lebih banyak daripada pasien dengan sikap negatif. Sikap merupakan reaksi atau respons yang masih tertutup dari seseorang terhadap suatu stimulus atau objek (Notoadmodjo, 2012). Hasil penelitian ini dapat terlihat bahwa apabila pasien memiliki sikap yang positif maka upaya pengendalian hipertensi yang dilaksanakan juga baik ataupun cukup baik. Green menyatakan bahwa perilaku kesehatan akan di pengaruhi oleh berberapa faktor salah satunya sikap. Sikap 
yang dimiliki responden akan memberikan dampak pada kesehatan responden itu sendiri, pengalaman pribadi menjadi dasar dari sikap seseorang yang akan membawa pengaruh terhadap kesehatannya (Heriyandi, 2017).

Pada Tabel 4 didapatkan data bahwa pasien yang patuh dan tidak patuh dalam menggunakan obat amlodipin.

Tabel 4. Kategori Kepatuhan Pasien

\begin{tabular}{lll}
\hline \hline $\begin{array}{l}\text { Kategori } \\
\text { kepatuhan }\end{array}$ & $\begin{array}{l}\text { Frekuensi } \\
\text { (orang) }\end{array}$ & $\begin{array}{l}\text { Persentase } \\
(\%)\end{array}$ \\
\hline Patuh & 56 & $74 \%$ \\
Tidak patuh & 20 & $26 \%$ \\
\hline Total & 76 & $100 \%$ \\
\hline \hline
\end{tabular}

Berdasarkan pada Tabel 4 didapatkan data bahwa $74 \%$ pasien yang patuh dalam menggunakan obat amlodipin dan $26 \%$ tergolong tidak patuh dalam menggunakan obat amlodipin. Hasil tersebut menunjukkan bahwa sebagian besar pasien patuh dalam menggunakan obat amlodipin. Kepatuhan dipengaruhi oleh beberapa faktor yang membuat kemampuan pasien untuk mengikuti perawatan secara optimal sering terganggu oleh beberapa penghalang, diantaranya: faktor sosial ekonomi, sistem perawatan kesehatan, karakteristik penyakit, terapi penyakit dan faktor yang terkait dengan pasien. Walaupun hasil yang didapat dari penelitian ini lebih banyak pasien yang patuh daripada yang tidak patuh, pasien tetap perlu diberikan informasi yang tepat terkait penggunaan obat sehingga dapat memberikan pengaruh yang besar terhadap pola pikir serta sikap pasien. Dengan begitu, pasien akan meminum obat dengan patuh sesuai indikasi, dosis, interval waktu minum obat amlodipin. (Mengendai et al, 2017).

Pada Tabel 5 didapatkan nilai yang bermakna antara pengetahuan terhadap kepatuhan pasien dalam menggunakan obat amlodipin.

Tabel 5. Hasil Uji Chi Square Pengetahuan dengan Kepatuhan

\begin{tabular}{|c|c|c|c|}
\hline $\begin{array}{l}\text { Nilai } \\
\text { Tabel }\end{array}$ & Signifikasi & Nilai $\alpha$ & Keterangan \\
\hline 0,031 & & 0,05 & $\begin{array}{l}\text { Terdapat } \\
\text { perbedaan }\end{array}$ \\
\hline
\end{tabular}

Berdasarkan Tabel 5 menunjukkan uji chi square untuk mengetahui adanya hubungan pengetahuan terhadap kepatuhan pengunaan obat amlodipin pada pasien hipertensi di Puskemas Arjuno Kota Malang. Didapatkan hasil nilai siginifikansi tabel (p) yaitu 0,031 yang lebih kecil dari nilai alpha 0,05 . Sehingga Ho ditolak dan dapat disimpulkan bahwa terdapat perbedaan yang bermakna antara kelompok kategori pengetahuan terhadap kepatuhan. Hal ini sejalan dengan teori yang dikemukakan oleh Lawrence Green, yang mana kepatuhan dipengaruhi oleh 3 faktor, yaitu faktor predisposisi, faktor pendorong, dan faktor pendukung. Pengetahuan termasuk pada faktor predisposisi (Notoadmodjo, 2012).

Pada Tabel 6 didapatkan nilai hubungan (korelasi) antara sikap terhadap kepatuhan pasien dalam menggunakan obat amlodipin.

Tabel 6. Hasil Uji Chi Square Sikap dengan Kepatuhan

\begin{tabular}{llll}
\hline $\begin{array}{l}\text { Nilai } \\
\text { Tabel }\end{array}$ & Signifikasi & Nilai $\alpha$ & Keterangan \\
\hline 0,002 & 0,05 & $\begin{array}{l}\text { Terdapat } \\
\text { perbedaan }\end{array}$ \\
\hline
\end{tabular}

Berdasarkan Tabel 6 menunjukkan uji chi square untuk mengetahui adanya hubungan sikap terhadap kepatuhan pengunaan obat amlodipin pada pasien hipertensi di Puskemas Arjuno Kota Malang. Didapatkan hasil nilai siginifikansi tabel (p) yaitu 0,002 yang lebih kecil dari nilai alpha 0,05 . Sehingga Ho ditolak dan dapat disimpulkan bahwa terdapat perbedaan yang signifikan (bermakna) antara kelompok pada variabel sikap terhadap kepatuhan pengunaan obat amlodipin pada pasien hipertensi di Puskesmas Arjuno Kota Malang. Hal ini sejalan dengan teori yang dikemukakan oleh Lawrence Green, yang mana kepatuhan dipengaruhi oleh 3 faktor, yaitu faktor predisposisi, faktor pendorong, dan faktor pendukung. Sikap juga termasuk pada faktor predisposisi (Notoadmodjo, 2012).

Pada Tabel 7 didapatkan nilai hubungan (korelasi) antara pengetahuan dan sikap terhadap kepatuhan pasien dalam menggunakan obat amlodipin.

Tabel 7. Hasil Korelasi Pengetahuan dan Sikap dengan Kepatuhan

\begin{tabular}{|c|c|c|c|}
\hline Variabel & P-value & OR & Keterangan \\
\hline Pengetahuan & 0,026 & 1,794 & $\begin{array}{l}\text { Terdapat } \\
\text { hubungan }\end{array}$ \\
\hline Sikap & 0,005 & 5,208 & $\begin{array}{l}\text { Terdapat } \\
\text { hubungan }\end{array}$ \\
\hline
\end{tabular}

Pada Tabel 7 dilakukan uji regresi logistik antara pengetahuan dan sikap terhadap kepatuhan penggunaan obat amlodipin. Didapatkan hasil p-value pengetahuan sebesar $0,026(\mathrm{OR}=1,794)$ dan sikap sebesar 0,005 $(\mathrm{OR}=5,208)$ maka terdapat hubungan antara pengetahuan dan sikap secara bersama-sama terhadap kepatuhan. Nilai OR sikap lebih tinggi daripada pengetahuan. Sehingga dapat 
disimpulkan sikap lebih besar mempengaruhi kepatuhan penggunaan obat amlodipin. Pengetahuan dan sikap sudah sesuai secara teori Lawrence Green mempengaruhi terhadap kepatuhan. Hasil ini juga dikuatkan oleh penelitian yang dilakukan oleh Runtukahu et al. (2015) juga didapatkan nilai p-value pada pengetahuan 0,026 (OR $=4,92)$ dan sikap didapatkan nilai $\mathrm{p}$-value 0,008 $(\mathrm{OR}=6,378)$. Pada penelitian di Langowan Timur ini dinyatakan terdapat hubungan antara pengetahuan dan sikap dengan kepatuhan, dan pada nilai OR sikap pada penelitian tersebut lebih besar daripada pengetahuan, maka sikap lebih besar mempengaruhi daripada pengetahuan (Runtukahu et al, 2015).

\section{KESIMPULAN}

Pada penelitian ini, meskipun lebih dari separuh responden memiliki pengetahuan yang baik, masih ada hampir separuh dari total responden yang pengetahuannya cukup sampai tidak baik. Mengingat pengetahuan dapat mempengaruhi kepatuhan minum obat, edukasi untuk meningkatkan pengetahuan sebaiknya terus dilakukan. Edukasi yang dilakukan hendaknya juga memfokuskan pada manfaat dari patuh minum obat sehingga sikap responden terhadap kepatuhan minum obat amlodipine ini dapat menjadi positif sehinggakepatuhan minum obat amlodipine menjadi meningkat.

\section{DAFTAR PUSTAKA}

\author{
Depkes RI 2012, Riset Kesehatan Dasar, \\ Jakarta: Badan Penelitian Dan \\ Pengembangan Kesehatan. Kementrian \\ Kesehatan Republik Indonesia.
}

Gama, IK, Sarmadi, TW, Harini, I 2014, 'Faktor penyebab ketidakpatuhan kontrol penderita hipertensi, Jurnal Keperawatan Politeknik Kesehatan Denpasar, 2(4), pp. 1-8.

Heriyandi, Hasballah, K, Tahlil, T 2017, 'Pengetahuan, sikap, dan perilaku diet hipertensi lansia di Aceh', Jurnal Ilmu Keperawatan, 6(1), pp. 1-13.

Mengendai, Yulike, Rompas, S, Hamel, RS 2017, 'Faktor-faktor yang berhubungan dengan kepatuhan berobat pada pasien hipertensi di Puskesmas Ranotana Weru', E-Journal Keperawatan, 5(1), pp. 1-8.

Notoatmodjo, S 2012, Promosi Kesehatan dan Perilaku Kesehatan, Jakarta: PT Rineka Cipta.

Runtukahu, RF, Rompas, S, Padang, L 2015, 'Analisis faktor-faktor yang berhubungan dengan kepatuhan melaksanakan diet pada penderita hipertensi di wilayah kerja Puskesmas Wolaang Kecamatan Langowan Timur', E-Jurnal Keperawatan, 3(2), pp. 19.

Sinuraya, RK., Dika, PD, Irmam M, Ajeng D 2017, 'Tingkat pengetahuan tentang hipertensi pada pasien hipertensi di kota Bandung', Jurnal Farmasi Klinik Indonesia, 6(4), pp. 290-297.

Sinuraya, RK, Dika, PD, Irma, M, Ajeng, D 2018, 'Tingkat kepatuhan pengobatan pasien hipertensi di fasilitas kesehatan tingkat pertama di kota Bandung', Jurnal Farmasi Klinik Indonesia, 7(2), pp. 124133.

Soenarta, AA, Erwinanto, Mumpuni, S, Rossana, B, Nani, HAA 2015, Pedoman Tatalaksana Hipertensi Pada Penyakit Kardiovaskuler, Edisi I, Surabaya: Perhimpunan Dokter Spesialis Kardiovaskular Indonesia. 